\title{
Attitudes of Physical Education and Classroom Teacher Candidates towards Teaching Profession in Turkey
}

\author{
Mehtap Yıldız ${ }^{1, *} \&$ Mahmut Gülle ${ }^{2}$ \\ ${ }^{1}$ Physical Education and Sports Department, Faculty of Education, Necmettin Erbakan University, Konya, Turkey \\ ${ }^{2}$ School of Physical Education and Sports, Hatay Mustafa Kemal University, Hatay, Turkey \\ *Correspondence: Physical Education and Sports Department, Faculty of Education, Necmettin Erbakan University, \\ Konya 42090, Turkey. E-mail: yildizmehtap77@gmail.com
}

Received: July 20, $2019 \quad$ Accepted: September 18, $2019 \quad$ Online Published: October 17, 2019

doi:10.5430/wje.v9n5p63 URL: https://doi.org/10.5430/wje.v9n5p63

\begin{abstract}
It is important to determine the attitudes of physical education teacher candidates who will carry out physical education courses in secondary and high schools and classroom teacher candidates who will carry out physical education courses in primary schools. The purpose of this study is to determine the attitudes of physical education and classroom teacher candidates towards teaching profession. The research was evaluated with a general survey model. The research group consisted of totally 280 teacher candidates; 168 of them study at School of Physical Education and Sports in Physical Education and Sports Teaching Department, 122 of them study at the Faculty of Education Primary School Teaching Department in the 2017-2018 academic year Hatay Mustafa Kemal University in Turkey. As data collection tools Personal Information Form developed by the researchers and the "Attitude Scale Toward Teaching (ASTT)" developed by Erkus (2000) et al. were used. In the statistical analysis of the data, t-test and one-way analysis of variance (ANOVA) were used. In the result of the research, it was determined that the attitudes of physical education and classroom teacher candidates towards teaching profession were high, but it was found that physical education teacher candidates had higher attitudes than classroom teacher candidates.
\end{abstract}

Keywords: physical education teacher, classroom teacher, teaching profession, attitude

\section{Introduction}

Individuals gain personality and self-respect phenomenon by learning and lead their lives with universal values. The teaching profession with its teacher identity is one of the most respected professions that transfer knowledge from generation to generation. Besides this, the social responsibility of teachers is increasing day by day (MONE, 2017).

In the last century, it is thought that updating the education system and to set new goals depending on the changes and developments are necessary. Therefore, countries should be able to incorporate the goals that will be in line with the demands of the changing needs and expectations into the educational vision (Hosgorur and Tastan, 2011). Among the elements in the education system, teachers, students and education program come to the forefront. Among these elements, the teacher has the highest power to impress others (Kiroglu, 2011). It is a known fact that the quality of educational services is directly proportional to the quality of the teacher. Thus, the teaching profession is important in determining both the quality and status of educational services (Mahiroglu, 2011).

In some European countries, the teaching profession has lost its characteristics to encourage prospective teachers to become teachers. According to the report of the European Commission (2013), the reasons for this situation are shown to be the decrease in the prestige of the teaching profession, poor working conditions and low salary. In order to increase the attitude towards teaching profession, professional satisfaction, social perception and working conditions should be changed positively (European Commission, 2015). Attitudes are the guiding forces behind the behaviors. Attitudes have a great importance both in interpersonal interaction and in all areas of communication (Inceoglu, 2000). A vital part of a person's attitudes take their final form in the period between the ages of 12-30. Especially between the ages of 21-30, which is called the first adulthood, the attitudes become increasingly unstable (Morgan, 2000). Specification of attitudes towards teaching profession is also important in terms of social and cultural dimensions. Especially if the positive and negative attitudes of the teachers and teacher candidates about the 
profession are determined, examined and discussed, the deficiencies and weaknesses of teacher training programs can also be determined (Gok, 2004).

In this context, it is thought that it is important to determine the attitudes of physical education teacher candidates who will carry out physical education classes in secondary and high schools and classroom teacher candidates who will carry out physical education classes in primary schools.

The purpose of this study is to determine the attitudes of physical education and classroom teacher candidates towards teaching profession.

\section{Methodology}

\subsection{Research Model}

The research was evaluated with a general survey model. The general survey model is based on the purpose of making generalizations and having ideas about the population through the data gathered from the sample (Simsek, 2012).

\subsection{Research Group}

The research group consisted of totally 280 teacher candidates; 168 of them (58 female, 110 male), study at School of Physical Education and Sports in Physical Education and Sports Teaching Department, 122 of them (87 female, 35 male) study at the Faculty of Education Primary School Teaching Department in the 2017-2018 academic year in Hatay Mustafa Kemal University in Turkey. It was preferred that the prospective teachers included in the research consisted of 2nd, 3rd and 4th grade students. First year students were not included in the study because they were in the period of orientation for the university and their departments.

\subsection{Data Collecting Tools}

In the research as data collection tools Personal Information Form developed by the researchers and the "Attitude Scale Toward Teaching (ASTT)" developed by Erkus (2000) et al. were used. The scale has a single factor structure consisting of 22 items. The validity and reliability of the scale was tested in four and five grades, and it was found to be valid and reliable in both. Five-point Likert-type scale was used in the evaluation of the scale and Cronbach's alpha reliability coefficient was found as 0.99 for five-point Likert-type rating. The lowest score that can be obtained from the scale is 22 and the highest score is 110. Scale articles; (1) Never Available, (2) Not Available, (3) Undecided, (4) Available and (5) Completely Available.

\subsection{Analyzing of Data}

In the statistical analyzing of data the SPSS 22.0 package program was used. The results were evaluated at $\mathrm{p}<0,05$ significance level. The normality test was used to determine whether the data fit the normal distribution. Since the number of participants $(\mathrm{n}=280)$ is over 30 , according to the Kolmogorov-Smirnov table; variables were in the $(\mathrm{p}>0,05)$ value and distributed in normal way. For this reason, from parametric tests; t-test and one-way variance analysis (ANOVA) were applied to the variables.

\section{Results}

In the tables below, the average scores of the teacher candidates from Attitude Scale Toward Teaching (ASTT) are presented.

Table 1. Attitude Levels General Scores of Teacher Candidates Toward Teaching Profession

\begin{tabular}{lcc}
\hline General Score & $\mathbf{N}$ & $\mathbf{x} \pm \mathbf{s d}$ \\
\hline Attitude & 280 & $58,96 \pm 7,85$ \\
\hline
\end{tabular}

In Table 1, when the general attitude scores of the teacher candidates attending the research were examined, it was determined that the teacher candidates' attitudes towards the teaching profession were high. 
Table 2. Comparison of Attitude Levels of Teacher Candidates Depending on Gender Variance

\begin{tabular}{lllccc}
\hline & Gender & $\mathbf{N}$ & $\mathbf{x} \pm \mathbf{s d}$ & $\mathbf{t}$ & $\mathbf{p}$ \\
\hline \multirow{2}{*}{ Attitude } & Female & 145 & $58,66 \pm 7,57$ &,- 666 &, 506 \\
& Male & 135 & $59,28 \pm 8,15$ & & \\
\hline
\end{tabular}

$\mathrm{p}>0,05$

In the Table 2 there was no statistically significant difference between total attitude scores of female and male teacher candidates $[\mathrm{t}=-, 666 ; \mathrm{p}>0,05]$.

Table 3. Comparison of Attitude Levels of Physical Education and Classroom Teacher Candidates

\begin{tabular}{clcccc}
\hline & Department & N & x \pm sd & t & p \\
\hline \multirow{2}{*}{ Attitude } & Physical Education Teacher Candidates & 168 & $61,44 \pm 6,33$ & 6,992 & $\mathbf{, 0 0 0}^{* *}$ \\
& Classroom Teacher Candidates & 112 & $55,25 \pm 8,46$ & & \\
\hline
\end{tabular}

$* * \mathrm{p}<0,01$

In Table 3, the attitudes of the teacher candidates participating in the research $[t=6,992 ; p<0,05]$. When the averages were taken into consideration, it was determined that physical education teacher candidates $(x=61,44)$ had higher attitudes towards teaching profession than classroom teacher candidates $(x=55,25)$.

Table 4. Comparison of Attitude Levels of Teacher Candidates Depending on Sports Activity Status

\begin{tabular}{lccccc}
\hline & Sports Activity Status & N & x \pm sd & t & p \\
\hline Attitude & Doing Sports & 170 & $58,89 \pm 7,44$ &,- 110 &, 913 \\
& Not Doing Sports & 109 & $59,00 \pm 8,48$ & & \\
\hline
\end{tabular}

$\mathrm{p}>0,05$

In Table 4, according to the teacher candidates' sporting status [t=-,110; $\mathrm{p}>0,05]$ there was no statistically significant difference between total attitude scores.

Table 5. Comparison of Attitude Levels of Teacher Candidates Depending on Financial Status

\begin{tabular}{|c|c|c|c|c|}
\hline & (I) Financial status & (J) Financial status & Mean Difference (I-J) & $\mathbf{p}$ \\
\hline \multirow[t]{12}{*}{ Attitude } & Low & Moderate &,- 55863 & ,988 \\
\hline & & High & 3,15606 &, 350 \\
\hline & & Very High & 4,53135 &, 157 \\
\hline & Moderate & Low &, 55863 & ,988 \\
\hline & & High & $3,71469^{*}$ &, $008^{* * *}$ \\
\hline & & Very High & $5,08998^{*}$ &, $006^{* *}$ \\
\hline & High & Low & $-3,15606$ &, 350 \\
\hline & & Moderate & $-3,71469^{*}$ &, $008^{* *}$ \\
\hline & & Very High & 1,37529 &, 857 \\
\hline & Very High & Low & $-4,53135$ &, 157 \\
\hline & & Moderate & $-5,08998^{*}$ &, $006^{* *}$ \\
\hline & & High & $-1,37529$ &, 857 \\
\hline
\end{tabular}

$* \mathrm{p}<0,05 \quad * * \mathrm{p}<0,01$

In Table 5, according to the financial status of the teacher candidates participating in the research, the attitudes towards teaching profession were moderate and high $(\mathrm{p}=, 008)$ and very high $(\mathrm{p}=, 006)(\mathrm{p}<0.01)$, high and moderate attitude and $(\mathrm{p}=, 008)$ between $(\mathrm{p}<0,01)$ level and very high attitude and moderate $(\mathrm{p}=, 006)$ there was a meaningful difference found at $(\mathrm{p}<0,01)$ level. 


\section{Discussion and Conclusion}

When the results in Table 1 are examined, it is concluded that both physical education and classroom teacher candidates' attitudes towards teaching profession are high. This result can be interpreted as the teacher candidates' attitude towards the profession is positive and they will do it voluntarily and willingly. There are some studies that show that classroom teacher candidates have positive and high attitudes towards teaching profession (Dogan and Coban, 2009; Serin et al., 2015; Aksoy, 2010; Ilter, 2009; Gologlu Demir, 2016). There are also studies in the body of literature reporting that physical education teacher candidates have a positive attitude towards teaching profession (Doganer and Ozbek, 2019; Nakip, 2015; Kalemoglu Varol et al., 2014; Sever, 2013; Abbasoglu, 2011).

Besides, Demirtas et al. (2011) 11 teacher candidates from different branches; Ozder et al. (2010) determined that pre-school and classroom teacher candidates' attitudes towards teaching profession were high.

Contrary to the findings of the study, Bakirci (2015) found that pre-service physical education teachers' attitudes towards teaching profession were not sufficient. Mangope et al. (2013), Pehlivan (2010), Bakar et al. (2008) determined that physical education teacher candidates' attitudes towards teaching were at moderate level.

When the results in Table 2 are examined, it is concluded that there is no significant difference between the male teacher candidates' attitudes towards teaching profession and female candidates. This result can be interpreted as that there is no difference between the attitudes of both male and female teacher candidates towards teaching profession, and that male and female teacher candidates' attitudes towards teaching profession are equally positive. Research findings supporting physical education and classroom teacher candidates were found. Nakip (2015) could not find a significant difference in terms of gender in the attitudes of physical education teacher candidates towards teaching profession. Ugurlu and Polat (2011) found that there was no difference between the attitudes of male and female classroom teacher candidates, but about female candidates they were more prone to teaching. In addition, the results of performed studies on teacher candidates from different branches have been reported (Demirtas et al., 2011; Ozder et al., 2010, Capa and Cil, 2000).

Actually, it is known in the body of the literature that there are researches indicating that the attitudes of female classroom teachers and physical education teacher candidates towards teaching profession are higher and more prone to teaching (Doganer and Ozbek, 2019; Gologlu Demir, 2016; Pehlivan, 2010; Ilter, 2009; Baykara Pehlivan, 2008; Capri and Celikkaleli, 2008; Bakirci, 2015). Yuvaci (2015) found that the attitudes of female physical education teachers who were graduated from physical education and sports schools towards teaching profession were higher than both male and female graduates of primary school classroom teachers and male graduates of physical education and sports school. After all, Unlu (2013) found that male physical education teacher candidates had higher attitudes towards the profession.

When the results in Table 3 are examined, it is concluded that physical education teacher candidates have higher attitudes towards teaching profession than classroom teacher candidates. This result can be explained that physical education teacher candidates are more willing to work as teachers than classroom teacher candidates. Also in this case, the teacher candidates in Turkey stems from the possibility of remote locations can be found in the place of their first assignment in city centers. It can be said that physical education teacher candidates are more positive towards the profession because of the high probability of teaching in the places close to the city centers and also conducting the physical education course which is considered as a more enjoyable and cheerful lesson.

However, Pehlivan (2010) determined that while physical education teacher candidates become teacher candidates with high attitude scores, attitudes towards teaching profession decreased in the last years. In this case, for the last 20 years as a teaching exam applied in Turkey can be shown as a reason. Karadag (2012) determined that the prospect of being a teacher exam influenced the way teachers perceived the teaching profession and therefore they experienced emotional burnout towards the teaching profession and became insensitive.

When the results in Table 4 are examined, it is concluded that the teacher candidates' status of doing or not doing sports has no effect on their attitudes towards teaching profession. This result can be interpreted as the fact that physical education teacher candidates or classroom teacher candidates do not affect their attitudes towards the profession. It can also be explained that there is no relationship between whether to play sports and the teaching profession. Nakip (2015) found that there is no significant difference in the professional attitudes of physical education teacher candidates according to their sporting activity status.

When the results of Table 5 are examined, it is concluded that there is a significant relationship between the teacher candidates' moderate financial status and high and very high attitudes. It was determined that the attitudes of the teacher candidates with high financial status and very high attitudes towards teaching profession had higher attitudes 
than the teacher candidates with moderate financial status. This result can be interpreted as teacher candidates' attitudes towards teaching profession increase as financial situation increases. In fact, although it is expected that the attitudes of low and moderate income teacher candidates towards the teaching profession will be higher, it is noteworthy that the attitudes of high-income teacher candidates are high. Contrary to the findings of the research, Ilter (2009) found that teacher candidates with lower and moderate level family incomes were more positive than the high income candidates in terms of their professional income.

Compared to the previous years, it is thought that the teaching profession is not seen as an important profession by the society. Ekici et al. (2017) found that teacher candidates stated that the teaching profession does not see enough value in the society. It can be said that the most important reason affecting this situation is related to education policies. For this reason, it should not be ignored that educational policies should be produced which will make the teaching profession attractive with its material and moral dimensions. Sharma et al. (2003) found that teacher candidates' attitudes and beliefs could be significantly affected by policies. However, it will be appropriate to revise the physical education and classroom teacher training programs in higher education and to reorganize the teacher candidates so that they can gain positive attitudes. If teacher training programs can be made more enjoyable and interesting, it can be said that teacher candidates will be willingly enrolled in these programs. Keating et al. (2002) found that physical education teacher training programs did not significantly affect the attitudes of physical education teacher candidates. This result can be explained that physical education programs are not capable of positively affecting the attitudes of teacher candidates.

In addition, it can be said that it is important to save the teaching experience and teaching practice lessons performed during teacher education from the format in which teacher candidates may acquire negative attitudes. Varcoe and Boyle (2014) found that teaching experience had a significant negative effect on the attitudes of teacher candidates.

However, it is also known that classroom teachers, who perform many courses, coincide with numerous problems especially while managing physical education classes. Morgan (2008) found that classroom teacher candidates does not consider physical education very valuable, that most of the teacher candidates does not prefer physical education and the employment of experienced teachers is important.

Consequently, it was determined that the attitudes of physical education and classroom teacher candidates towards teaching profession were high, but it was determined that physical education teacher candidates had higher attitudes than classroom teacher candidates. Besides, it has been determined that teacher candidates who have high and very high financial status have more positive attitude towards teaching profession than those who have medium financial status. For the future research, it is recommended to carry out qualitative research towards teaching profession.

\section{References}

Abbasoglu, E. (2011). Determination of the level of self respect and the attitude of the traniee teachers in the physical education department. Unpublished Master's Thesis, Karadeniz Teknik University Education Sciences Institute, Trabzon, Turkey.

Aksoy, M. E. (2010). Pre-service teachers' attitudes towards teaching profession (Gaziosmanpasa University Sample). Social Sciences Research Journal, 2, 197-212.

Bakar, A. R., Konting, M. M., Jamian, R., \& Lyndon, N. (2008). Teaching efficacy of Universiti Putra Malaysia science student teachers. College Student Journal, 42(2), 493-509.

Bakirci, Y. (2015). Investigation of attitudes of prospective physical education teachers towards the profession of teaching. Unpublished Master's Thesis, Aksaray University Social Sciences Institute, Aksaray, Turkey.

Baykara-Pehlivan, K. (2008). A Study on pre-service classroom teachers' socio-cultural properties and their attitudes toward teaching occupation as a subject. Mersin University Journal of the Faculty of Education, 4(2), 151-168.

Capa, Y., \& Cil, N. (2000). To examine the attitudes of pre-service teachers towards teaching profession with regard to different variables. Hacettepe University Journal of Education, 18, 69-73.

Capri, B., \& Celikkaleli, O. (2008). Investigation of preservice teachers' attitudes towards teaching and professional self-efficacy beliefs according to their gender, programs, and faculties. Inonu University Journal of the Faculty of Education, 9(15), 33-53.

Demirtas, H., Comert, M., \& Ozer, N. (2011). Pre-service teachers' self-efficacy beliefs and attitudes towards profession. Education and Science, 36(159), 96-111. 
Dogan, T., \& Coban, A. E. (2009). The investigation of the relations between students' attitude toward teaching profession and anxiety level in faculty of education. Education and Science, 34(153), 157-168.

Doganer, S., \& Ozbek, O. (2019). Thoughts of physical education teacher candidates related to their attitudes towards professional ethics principles and teaching. Spormetre The Journal of Pysical Education and Sport Sciences, 17(1), 197-208.

Ekici, G., Bas, M., \& Kizilkaya, O. (2017). Determination of perception regarding the teaching profession of teacher candidates: A work of metaphor analysis. International Journal of Eurasia Social Sciences, 8(28), CCLXXXVIII-CCCXIII.

Erkus, A., Sanli, N., Turkan Bagli, M., \& Guven, K. (2000). Developing an attitude scale toward teaching as a profession. Education and Science, 25(116), 27-33.

European Commission/EACEA/Eurydice. (2015). Avrupa'da ogretmenlik meslegi: uygulamalar, algllar ve politikalar. [Teaching profession in Europe: practices, perceptions and policies]. Eurydice Report. Luxembourg: European Union Publications Office. ISBN 978-92-9201-886-3 https://doi.org/10.2797/031792

Gok, F. (2004). Teacher attitude. 13. National Educational Sciences Congress Abstract Reports (6-9 July). Inonu University Faculty of Education. (H. Atilgan \& I. Cinar, Eds.). Malatya, Turkey: Pegem A Publishing, 269.

Gologlu Demir, C. (2016). Determination of classroom teachers' extra-curricular time use for professional tasks and their attitude towards teaching profession. Unpublished Ph.D. Thesis, Gazi University Educational Sciences Institute, Ankara, Turkey.

Hosgorur, V., \& Tastan, N. (2011). Egitimin islevleri. [Functions of education]. In O. Demirel \& Z. Kaya, (Eds.). Egitim bilimine giris. [Introduction to education]. Ankara, Turkey: Pegem Academy, 281-306.

Ilter, I. (2009). Research on attitudes of teacher candidates toward teaching profession in terms of some variants. Unpublished Master's Thesis, Firat University Social Sciences Institute, Elazig, Turkey.

Inceoglu, M. (2000). Tutum algi iletisim. [Attitude perception communication]. Ankara, Turkey: Imaj.

Kalemoglu Varol, Erbas, M. K., \& Unlu, H. (2014). The predictive power of occupational anxiety levels of prospective physical education teachers upon their attitudes towards the teaching profession. Spormetre The Journal of Pysical Education and Sport Sciences, 12(2), 113-123. https://doi.org/10.1501/Sporm_0000000259

Karadag, R. (2012). The attitudes of Turkish language teacher candidates towards teaching profession and their reasons for selecting the teaching profession. e-Journal of New World Sciences Academy, 7(2), 44-66.

Kiroglu, K. (2011). Bir meslek olarak ögretmenlik. [Teaching as a profession]. In O. Demirel \& Z. Kaya (Eds.), Egitim bilimine giris. [Introduction to education]. Ankara, Turkey: Pegem Academy, 343-372.

Keating, X. D., Silverman, S., \& Kulinna, P. H. (2002). Preservice physical education teacher attitudes toward fitness tests and the factors influencing their attitudes. Journal of Teaching in Physical Education, 21(2), 193-207. https://doi.org/10.1123/jtpe.21.2.193

Mahiroglu, A. (2011). Ögretmenlik mesleği ve öğretmen yetiştirmede gelişmeler ve yenilikler. [Developments and innovations in teaching profession and teacher training]. In O. Demirel \& Z. Kaya, (Eds.), Egitim bilimine giris. [Introduction to education]. Ankara, Turkey: Pegem Academy, 373-419.

Mangope, B., Mannathoko, M. C., \& Kuyini, A. B. (2013). Pre-service physical education teachers and inclusive education: attitudes, concerns and perceived skill needs. International Journal of Special Education, 28(3), $82-92$.

Millî Egitim Bakanligi [Ministry of National Education (MONE)] Ogretmen yetistirme ve gelistirme genel mudurlugu [General directorate of teacher training and development]. (2017). Ogretmenlik meslegi genel yeterlikleri. [General competencies of teaching profession]. Retrieved from https://oygm.meb.gov.tr/meb_iys_dosyalar/2017_12/06172441_Ygretmenlik_Meslegi_Genel_Yeterlikleri.pdf

Morgan, P. (2008). Teacher perceptions of physical education in the primary school: attitudes, values and curriculum preferences. The Physical Educator, 65(1), 46-56.

Morgan, C. T. (2000). Psikolojiye giris. [Introduction to psychology]. (Trans. H. Arici \& O. Aydin). Ankara, Turkey: Meteksan.

Nakip, C. (2015). The relation between preservice teachers' confidence in self efficiency and their attitudes toward teaching profession. Unpublished Master's Thesis, Abant Izzet Baysal University Educational Sciences Institute, 
Bolu, Turkey.

Ozder, H., Konedrali, G., \& Zeki, C. P. (2010). Examining the attitudes towards the teaching profession and academic achievements of prospective teachers. Educational Administration: Theory and Practice, 16(2), 253-275.

Pehlivan, Z. (2010). Analysis of physical self-perceptions of physical education teacher candidates and their attitudes toward teaching profession. Education and Science, 35(156), 126-141.

Serin, M. K., Gunes, A. M., \& Degirmenci, H. (2015). The relationship between the attitudes towards teaching profession and the anxiety level of prospective primary school teachers. Cumhuriyet International Journal of Education, 4(1), 21-34. https://doi.org/10.30703/cije.321360

Sever, O. (2013). Investigation of physical education teachers' attitudes on teaching profession and self-esteem. Unpublished Master's Thesis, Kahramanmaras Sutcu Imam University Institute for Graduate Studies in Science and Technology, Kahramanmaras, Turkey.

Sharma, U., Ee, J., \& Desai, I. (2003). A comparison of Australian and Singaporean pre-service teachers' attitudes and concerns about inclusive education. Teaching and Learning, 24(2), 207-217.

Simsek, A. (2012). Arastirma modelleri. [Research models]. In A. Simsek (Ed.), Sosyal bilimlerde arastirma yontemleri. [Research methods in social sciences]. Eskisehir, Turkey: Anadolu University Publishing.

Ugurlu, C. T., \& Polat, S. (2011). The attitudes of elementary education students towards teaching profession. Cumhuriyet University Journal of Social Sciences, 35(1), 68-74.

Unlu H. (2013). Do prospective physical education teachers really want to be physical education teachers?. Croatian Journal of Education, 15(4), 211-230.

Varcoe, L., \& Boyle, C. (2014). Pre-service primary teachers' attitudes towards inclusive education. Educational Psychology, 34(3), 323-337. https://doi.org/10.1080/01443410.2013.785061

Yuvaci, H. (2015). Comparison of attitudes of physical education teachers and school teachers toward teaching profession. Unpublished Master's Thesis, Abant Izzet Baysal University Educational Sciences Institute, Bolu, Turkey. 